\title{
Upgrading Pre-Literacy Skills of Disadvantaged Children
}

\section{Shireen Zafarullah}

\section{The First Step Towards a Combined Syllabus for all Children in Pakistan}

Prescription of a common syllabus for all children in Pakistan is the demand of social activists. The author feels that this is not a feasible proposal at this time as there is a huge gap between the life experiences in the two worlds that exist within Pakistan ---the world of the privileged and the world of the deprived. Children of the poor fail to develop certain essential pre-literacy skills (Zafarullah, 1996) and are therefore unable to compete with their more fortunate counterparts. These underprivileged children lack an orientation towards literacy:

1. They lack certain essential pre-literacy skills,

2. Their home language is different from the school language,

3. They lack the motivation to become literate.

Privileged children, on the other hand, have few such shortcomings. In fact they are overly motivated, competent and competitive in the area of school learning. Hence, if we have a combined syllabus we will either have to downgrade the educational standard of the advanced children (bringing them down to the level of the backward children) or up-grade the disadvantaged children and take them closer to the level of their more fortunate counterparts. The second option is obviously more desirable.

This paper briefly describes some of the methods employed by the researcher to rapidly upgrade under-privileged children before and during elementary schooling. These methods have been implemented and tested by teams led by the researcher and have proved dramatically successful.

\section{How to Upgrade the Under-privileged Children.}

In order to upgrade deprived children and bridge the gap between privileged and underprivileged children, we will have to start early and work at a faster pace than normal. The influence of generations of illiteracy cannot be eliminated in a day. Homes with illiterate parents lack literacyrelated activities, demonstrations, artefacts, materials and insight (MSc 
Research Report, 1994). We will need to muster all possible resources to overcome these handicaps of the disadvantaged children from all three sides.

1. By preparing them for school (or by developing missing school readiness in them) before they come to school so that their chances of failure and drop out at school are reduced.

2. By attracting them to school, by making school learning more relevant, meaningful, interesting and functional for them.

3. By motivating parents of disadvantaged children to send them to school by developing an awareness about the need for education in them.

\section{Preparing Young Children for School}

In her recent research the author Zafarullah 1996 has revealed that the children of illiterate under-privileged parents are grossly handicapped as compared to those of educated parents. Hence they face many difficulties in the course of their studies. Only by removing these handicaps can we prepare them for school. We will first discuss these handicaps before we proceed to find out methods to minimise them. The handicaps include:

\section{i) Unfamiliar school language}

The primary handicap is the language handicap. A majority of Pakistani children speak their regional language in their homes, while they are taught in the national language at school. Hence they are unable to understand the instructions and lessons at school. This difficulty is faced by them in their first quaida. When they read the letter and see the picture of watermelon, they are supposed to say , However a watermelon to them is

So they say and get confused.

\section{ii) Lack of motivation to become literate}

The second handicap faced by these deprived children is a lack of initiative and motivation to become literate. Their illiterate home background is primarily responsible for this apathy towards literacy/ education. It is not easy for the educated to realise that most of these homes do not contain a scrap of printed or written paper. There is hardly any literacy related activity in them; activities which can support or motivate them to become literate. Because these children do not see anybody read or write around them they do not 
realise the importance of being literate. Hence, the other most important goal of the literacy programme should be to expose these children to the act of reading and writing and other literacy related experiences, which they have missed.

The best way to do so is as follows:

1. Through exposing them to print in their environment

2. Through the language experience approach to reading.

\section{iii) Lack of School Readiness (or Readiness to Learn)}

The third most important handicap these children face is a lack of school readiness among them. According to Morrison (1988) school readiness means the attainment of pre-requisite skills, knowledge, attitude, motivation and behavioural traits that enable the learner to profit maximally from school instruction. The most important prerequisites to school readiness are pre-literacy skills (Walach \& Walach, 1978). These skills were found to be missing in underprivileged children when they were tested on the Boehm Cognitive Test Battery by Zafarullah (1996). These test items and their related skills are given below:

Pre-Literacy Skills

Language Skills

Pre-Reading Skills

Pre-Writing Skills

Pre-Number Skills
Test Items (of Boehm Cognitive Test Battery)

Story Comprehension Vocabulary Skill

Letter Naming Auditory discrimination

\section{Symbol Discrimination} Muscle Co-ordination

\section{Number Knowledge Multiple Direction}

The two most significant pre-academic handicaps related to the promotion of literacy were found to be in the skills of:

* Auditory Discrimination (or Sound Phonics Discrimination)

* Symbol Discrimination (or letter, number, Shape recognition) 
a) The disability to discriminate between different sounds is also transmitted to these children from their illiterate parents. Poor, uneducated parents are unable to teach the subtle difference between sounds to their children because they are themselves not aware of it; besides they have little time and energy left for the teaching of this demanding job.

Unfortunately, when children come to school this handicap is further enhanced. This is because when they are taught letters, the teacher only introduces the letter name or shape to them, not the letter sound. For example the shape of the letter " "is introduced along with letter name " "but the letter sound " " is not given due importance.

In fact the real identity of each letter is its sound. Words are coined only after joining (synthesising) these sounds, which are printed out in the shapes of these letters. Most teachers in Government schools have to teach more than one class at a time. They therefore ask the older and brighter children in the school to teach the primary classes. These tutor children read out letters, words and sentences and young children repeat after them. Thus the lessons are learnt through the rote method without the development of the required understanding. The new comers are neither able to form words by joining letter sounds nor are they able to break (analyse) words into letters. They learn to recite letters by heart from

to but are unable to join letter sounds to form words. This is why while teaching alphabets to young children it is necessary to tell them that:

* each word has a name;

* $\quad$ each word has a shape;

* $\quad$ each word has a sound;

Because this handicap (which is shared by under-privileged children all over the world) is a great hurdle in learning, special experiences can be planned in the programme to improve it. Such experiences which involve vocalisation and articulation of different sounds, letters, words and sentences.

b. Disability to recognise and differentiate between letter and number shapes has also been observed in test results. Shape recognition can be promoted in the literacy programme through various means. Many interesting and creative techniques can be used to familiarise children with various letter and number shapes in this manner: 
* By comparing these shapes with similar shapes in the environment.

* $\quad$ By colouring the letter or number shapes.

* By joining dots to form letter and number shapes.

* By completing incomplete letter and number shapes.

* $\quad$ By joining similar letter shapes with lines or marks.

By compensating for these handicaps, in time we can bridge the gap between the privileged and underprivileged children before they enter regular school, so that when these disadvantaged children come to school in grade-one they do not get a cultural shock but enter the main-stream of education with ease.

To sum up this issue, we can conclude that the under-privileged children fail to develop these skills because they lack proper environmental stimulation i.e. their home environment is not conducive to verbalisation. It is devoid of literate parents and hence lacks literacy-related experiences and activities.

However, it has been proved through successful intervention (Zafarullah) that these handicaps can be compensated and deficiencies reversed, through early enriching and stimulating experiences. These enriching experiences in the area of reading, writing, number and language development can be imparted with the help of new and interesting media.

Prakasha (1983) has shown that during the child's early life wholesome forms of intervention in his milieu can help him grow like normal children, shedding the imprints of a mediocre initial learning environment. Morrison's (1988) rationale was that it is less costly in the long run to prevent in the pre-school (and primary) years than it is to remedy in the high school. At the same time, besides being more expensive, remediation was not as effective as prevention. Therefore, it is at this stage of education that we get the best return from intervention through enrichment and compensation.

\section{Attracting Disenchanted Children to School}

Learning experience at the Government schools in Pakistan is monotonous and prosaic. Young deprived children who are not interested in schooling find it even more dull and dry. They drop out and fail because they cannot maintain their attention and interest in this formal learning for long. If we wish to attract these children to school we have to give them 
stimulating experiences in an informal and relaxed manner, so that they develop a healthy and happy association with early school life.

Children who come from well to do homes find school more attractive, because they are familiar with school learning. However, for the less privileged children school can be made attractive. This can be done with the help of new media of education. These media, though informal, have to be more meaningful, relevant and attractive.

After a thorough study of the successful and well-known enrichment programme such as the Head-Start, the author selected some new media for her early enrichment programme (to develop School Readiness in the Underprivileged Children of Basti Saiden Shah Lahore). The response of the intervention group was very encouraging as observed from the formal (MRT adapted) test results and informal assessment by local and foreign funding agencies (SPO, CIDA, woman's division etc.). The same media can be exploited for any other literacy programmes in order to attract children to school. These enriching teaching media include:

$\begin{array}{ll}* & \text { environmental media } \\ * & \text { language media } \\ * & \text { play media } \\ * & \quad \text { creative media }\end{array}$

\section{Environmental Media}

The programme that nourishes emergent literacy requires a literacy rich classroom environment. Such an environment can be developed with the help of: (1) Print all around the classrooms (2) a special literacy centre:

i) Environmental Print in the Classroom. It is proposed that besides the literacy corner, the whole classroom may be littered with environmental print in different ways and styles. Latest research findings (Leichter 1984) suggest that first words can be read more easily if the environment is filled with print that is used regularly for functional purposes.

Teachers can promote interest in print by displaying familiar (ambient) print in the classroom (Schwart 1991). Since children are used to seeing these logos in their home environment they easily relate and learn from them e.g. logos of familiar brands like CocaCola. Some children may not notice this print on their own. It is 
therefore the teacher's job to point out the theme letter in the familiar print and to develop a relationship between the two. Print can also be presented in the shape of labels and words. The teacher's role in this connection is to help children to understand the predictability of print in a wide variety of contexts.

ii) The Literacy Centre should be located in a quiet corner of the room or in a side room. It should include a library corner, writing area, language or audio area with a cassette player. Books in this area should be shelved by category or colour code (if possible). The many types of books collected in this area may include fairy tales and other storybooks, picture concept books, information books, nursery rhymes and poetry books.

\section{Language Media}

Language is the base for all literacy learning. But language is one area in which deprived children manifest the greatest handicap. Experience in this area can greatly enhance the success of the programme. The main purpose of language experiences for the children is to help them:

* Understand the school language.

* Expand their school language.

Language being the key to all learning, it has an important role to play in the early learning of the child. However, any learning that is related to the social heritage of the children is more relevant. Hence, when children are taught in their own language they learn easily. Efforts should be made through research to induct the salient words of each dialect in the early literacy programmes, especially until children are made familiar with the second (national) language.

The language experience approach gives children a chance to share their experience with others and develop their oral language skills as well. In order to learn to read, children must be able to connect the spoken word with the printed word. According to the language experience approach teachers are supposed to encourage the children to express their ideas, experiences and thoughts from the very first day. As they express themselves teachers are told to write what they say and read it out to the class in the end so that children develop an understanding that:

* what they think or say can be written; 
* what is written can be read;

* what is read can again be written;

Besides the language experience approach discussed below, many more language promoting techniques may be used in the programme such as oral stories, reading stories and story re-enactment experiences.

Oral story telling is at the back of all literacy. It is the most powerful and effective way to teach any language, as it touches the heart in a way that mere facts can not. A wise person once said "what the heart knows today the head will understand tomorrow". Any teaching that is done through the heart or which involves the feelings is more effective than that which is emotionless. Children build their storehouse of language from their stories and also develop the concept of story from them.

Reading Stories (Poems \& Literature) People who teach young children generally agree that children who learn to read early are the ones who have been read to. Keeping this in mind we have proposed to incorporate reading of both rhymes and stories as an important part of this programme.

Selection of books for young children. The earliest literature shared with children is more often sung and recited from memory than read. Besides the nursery rhymes, three kinds of books are recommended: story books, information or concept books, and picture phrase books. In Pakistan there is a great shortage of books, especially of the last two categories. It is therefore recommended that special efforts be made to publish more books of this category.

Recent research has shown that story telling, book reading and story re-enactment were the activities, which developed awareness for language through the development of meta-linguistic words and sentences. And since the development of awareness for language was found to be concomitant to the learning of literacy, the programme should make provisions for experiences, which promoted reflective thought among these young children.

\section{Play Media}

Play has been selected as an important medium of instruction because during play the child is relaxed and generally exhibits above-average behaviour. Play is a particularly productive context for learning by young children. It is a comparatively less frustrating and more inspiring activity because it is: 
* a more voluntary activity;

* a more successful experience.

Before they go to school children persistently make leaps in their development by playing. However, most parents have to be convinced that play is hard work in any area of learning at this stage of life. Play has been used as a tool of education by most of the traditional early childhood educationists in the West. Both Froebel (1976) and Montessori (1956) used natural play as the main source of experience in learning.

Before 1970 one of the most popular childhood theories (the psychoanalytic theory) maintained that the main function of play was to enable children to work out their inner conflicts (Spodek 1974), especially play which was free and spontaneous. Hence it was believed that adult intervention would not only disrupt play but also hamper children from expressing their feelings. The latest cognitive theories of Piaget (1986) and Vigotsky (1978) have changed this attitude. It is now realised that play not only resolves inner conflicts and drains aggressive feelings, but also promotes cognitive and intellectual development. And since cognitive development is related and supported by teachers, therefore their participation and intervention in such play activities has a positive effect, not only on the children's play, but also in the social and intellectual development of these children.

Modern psychologists believe that play without the element of fun ceases to be play. They also believe that the greatest amount of pleasure is derived from free and spontaneous play. Great importance is therefore attached to free play in educational programmes for young children in the West. However, free play is not feasible in a large group; therefore they are forced to keep the group size small.

The conditions in our country are somewhat different. We have to educate millions. We cannot afford free play involving small group size and expensive equipment. Moreover our young children are more manageable even in a large group. We have therefore succeeded in imparting a structured programme with structured play activities for large groups of more than 50 children.

Through a successful structured (planned, guided and monitored) programme we have proved that with interesting and attractive experiences one can maintain the attention of children without giving them total freedom of expression. Moreover, we have shown that these structured play activities which are a medium of (social and intellectual) growth can also 
help in the promotion of literacy. The connection between the two can be developed under the following four categories:

* Physical and Fanctional Play is that play through which the child uses his larger muscles to develop his motor skills and drain his negative feelings and emotions. This play has no direct bearing on the development of literacy skills. However, by reducing emotional tension it indirectly promotes learning. Hence, physical play is specially needed for tense hyperactive children in overcrowded classrooms.

* Manipulative (constructive and creative) Play involves the tactile senses. It helps in the development of finer muscle control, hand eye coordination and creative abilities in the child. It is a source of achievement and satisfaction to the child. But it is not directly related to any one of the pre-literacy skills except writing. However, it can aid in relaxing the children and in the development of their muscle power.

* Dramatic (pretend and cognitive) Play promotes the development of language and imaginative skills in the child. A series of research studies (Williamson \& Silverson 1991) have shown that thematic fantasy (dramatic) play like teacher-guided story re-enactment increases children's comprehension and recall of stories. However, it has been observed (during applied research) that repeated book reading aloud by teachers and access to books for independent reading is all that is needed to get some children to engage in story re-enactment.

* Games are a form of highly structured play. They follow specific rules that must be observed. Often these activities are not included in the early programmes for young children because it is felt that they are too difficult for them. However, four to five-year-old children are beginning to move into this stage where game play is possible, especially games which have music components. Different games can therefore be developed for the literacy programme. The local and traditional games of our culture can be used to motivate children into literacy. A survey in each area could be made to find them and include them in these programmes.

We were surprised to note that despite the limited space to move about both at home and at school, our under-privileged child is not as restless as we would expect of a child in his circumstances. Zafarullah (1996) therefore has proposed more indoor cognitive play activities for these peaceful children than out-door physical play activities. The experiences include relatively more games and dramatic play activities than physical and manipulative play. Beside indoor board games, the programme should 
encourage the use of dramatic play, because this is an activity in which children operate at a higher cognitive level than usual.

* Teacher Role in Educational Play. If play has to be educational the teacher has a prime role in setting the stage for play in guiding its direction and in modifying it. Apparently some teacher support is needed to get literacy play started. Latest research findings suggest that teacher guidance can be an important factor in helping children integrate literacy into their play. Moreover, educational play at this age level has to be continuously monitored by teachers. However a single teacher cannot successfully monitor such a large group single-handedly, unless it is a planned and structured experience. Therefore, we have proposed structured and planned games involving the whole class (of 50 children) at one time.

It should be remembered however, that in order to retain the playfulness of the play teachers have to be careful about the degree to which they impose themselves on the play. Children should not at any stage be reprimanded for making wrong moves. Especially in case of dramatic play situations, it is best to leave the children in command, otherwise the teacher's involvement may disrupt the play.

\section{Creative Media (Art and Music)}

Although creative media have no direct relation with the development of early literacy creative activities, (like physical play) both relax the children and instigate them into learning. Art designs introduce children to letter shapes and music invigorates and brings life into their otherwise dull academic learning. We therefore recommend that both music and art be incorporated into all literacy-related activities and programmes.

\section{Motivating the Parents of Disadvantaged Children to Send Their Children to School}

Most under-privileged parents are illiterate and hence have no affiliation with any school. They are in fact in awe of the whole concept of schooling. Moreover they regard the educated teacher as a super human person. Teachers and other school personnel, exploit this situation and add fuel to the fire by their unreasonable demands and behaviour. The fear and inhibitions of the parents can be reduced to a great extent by improving the attitude of school authorities towards the concerned parents (and families) of the children.

We feel that the best way to do so is by increasing the influence and participation of the parents in the affairs of their children. The fact that 
100 The Lahore Journal of Economics, Vol.3, No.1

they are not literate should not stop them from having a say in a place of their own interest. Only when school authorities are answerable to interested parties i.e., the parents, will they try to serve their interest.

What is happening today is that people who sit at a great physical and mental distance from them run public schools. As a result there is total lack of accountability. Educational funds are therefore going down the drain and there are schools that are found to be only on paper.

Besides controlling school affairs the parents can be involved in most of the activities through Parents Teacher Association (PTA) meetings. These meetings should be given due importance and held regularly.

Another reason for the lack of parental incentive for schooling is that it cannot be related with any gainful employment. When they see their less educated offspring earn more and at an earlier stage of life (as child labour) than their more educated ones, they lose all interest in education. The situation can be improved by better educational planning for the future : giving greater incentives to parents who send children to school; making education conditional for employment and planning more functional educational programmes. To sum up, we have some important recommendations regarding the educational upgradation of deprived children in the early stages of their lives.

\section{Recommendations}

It is recommended that the early childhood education be given due importance in educational planning, and learning experiences be planned more seriously for the young child than is being done today in Pakistan. It is at this stage that the foundations of literacy are being laid, and if these foundations are week, then the whole structure built on it is liable to collapse. Research has shown that this age is the most productive time to teach, because maximum learning can take place at the stage when the young child is intrinsically motivated to learn and achieve. A little support at this age from the environment can greatly help.

It is also recommended that the under-privileged child be helped to overcome his handicap caused by an unstimulating environment. It is the job of the educational planners to help him exploit his strengths and compensate his handicaps through enriching experiences in his home or at school before he is lost in the mainstream of education.

To avoid this wastage it is recommended that an additional preparatory class be added to the current school structure, and all children 
found to be deficient in school-readiness inducted into this class, in order to prepare them for the more formal learning they will encounter at regular school. It is further recommended that the special class be tailored to the needs of these children rather than children be tailored for it.

The pre-academic status of these children should be elevated by timely intervention (through compensation, stimulation and enrichment).

- The intervention should be based on research, both at the planning stage (to find the particular needs and handicaps of the target group), and at the end to assess the success of the programme. It is therefore suggested that a National Council of Educational Assessment be constituted which should prepare a standardised test for needy children.

- $\quad$ Foreign intervention models may be studied and consulted but not copied blindly, as our own disadvantaged children have their own special needs.

- Intervention should be focused on the special needs and related academic handicaps of these children, handicaps which result in a lack of school readiness among children, as a result of which they fail and drop-out en-masse in elementary grades.

- Intervention be carried out with the help of interesting, invigorating, absorbing and innovative media. Media like a modified environment, language, play and creative media (art and music) are most suitable for the purpose.

- It is further suggested that all prospective pre-school enrichment programmes for disadvantaged children should have a strong component of the following:

Formal evaluation at both the formative and summative levels.

Relevant, meaningful and functional experiences.

The aim of all the earlier recommendations is to build an insight into the needs, problems, strengths and capacities of disadvantaged children in particular and all children in general.

\section{Suggestions for the Development of Educational Materials}


102 The Lahore Journal of Economics, Vol.3, No.1

(i) An important suggestion for this programme is the development of indigenous educational toys for young children. It would be helpful if the government was to take up the responsibility of developing such toys that promote literacy before school, which are inexpensive and attractive and which motivate children to learn.

(ii) The present study has highlighted the role of stories and book reading. But unfortunately there are not enough books written for young children in the local market. It is suggested therefore, that a research cell be developed with the sole purpose of helping in the writing and publishing of story books. This cell could hire professional artists and story writers.

(iii) Finally, it is suggested that programmes in which stories are related to children may be developed for TV and radio, with a conscious effort of all literate people. Programmes such as 'Sesame Street' on TV can introduce the young deprived child to the concept of print, letters, numbers and other literacy skills.

To sum up, it can be concluded that educating millions of neglected children in Pakistan is not an impossible task. One simply needs to upgrade the pre (\& post) literacy status of these children by: carefully planning relevant and enriching experience for them; imparting these experiences in a proper sequence (i.e. achieving one goal at a time) \& developing fool proof but simple tools to monitor their success. However, the programme may be replicated only after first trying it at a smaller scale. The entire nation should be involved in this most important nation building activity. Especially the literate few among them should be made to realise that their being puts a greater responsibility on them. 


\section{References}

Boehm A, E. and Slater, B, R. 1974. Cognitive Skills Assessment Battery Teacher College Press.

Clarke M.M, 1976. Young Fluent Readers London, Heinea Educational Books.

Froebe1, F. 1974. The education of man. Clifton, NJ: Augustus M. Kelly.

Leicher Hope Jensen 1984. Families as environments for literacy. Awakening to literacy. University of Victoria, Victoria Canada. Heinemann Educational Books London.

Manson M. Peterman C.L. Bonnie M.K. 1988. Reading to Kindergarten children, Editors Strickland and Marrow Book Emerging Literacy. INA Delaware.

M.Sc. 1990 students, College of Home Economics, Lahore. Report on Literacy related materials and activities in the home.

Morrison George 1988. Early Childhood Education Today. Merril Publishing Co. Columbus, Toronto, London.

Nurssj, R. and McGauvran, M. E., 1986. Metropolitan Readiness Tests. The Psychological Corporation Harcourt Joveanocivh, Inc.

Pakistan Educational Journal. July-Oct-1990. Source: Central Bureau of Education 1990.

Piaget, J.Inhelder, B. 1986. The Psychology of the Child. Basic Books, Inc. New York.

Prakasha, Veda, 1983. "Battling costs for Quality and Quantity, Response in early childhood care and education". Digest II UNESCO/UNICEF Publication.

Schwat J.I. 1988. Encouraging early literacy. Heinemann Educational Books, Inc.

Seginer R., 1980. "The effects of cognitive and effective variables on academic activity: A Multivariate Analysis". Contemporary Educational Psychology. 1980 July Vo1., 5(3) 266-275. 
104 The Lahore Journal of Economics, Vol.3, No.1

Spoked, B., 1982. The kindergarten: A retrospective and contemporary view. In L. Katz (Ed.) Current topics in early childhood education, Vo1 IV. (pp. 173-192). Norwood, NJ: Ablex.

UNESCO, 1992. Situation Analysis of Children and Women in Pakistan Universal Primary Education for girls.

Vygotsky, L.S. 1978. Mind in society: The development of psychological process. Cambridge, MA: Harvard University Press.

Wallach A. Micheal. Walach Lise, 1976. Teaching all children to read. The University of Chicago Press, Chicago, London. 